\title{
"Snared by Words": Trauma and the Shoah in the Poetry of Medbh McGuckian
}

\section{Shane Alcobia-Murphy}

\section{(2) OpenEdition \\ 1 Journals}

\section{Electronic version}

URL: http://journals.openedition.org/etudesirlandaises/2163

DOI: 10.4000/etudesirlandaises. 2163

ISSN: 2259-8863

\section{Publisher}

Presses universitaires de Rennes

\section{Printed version}

Date of publication: 30 June 2011

Number of pages: $109-120$

ISBN: 978-2-7535-1348-8

ISSN: 0183-973X

\section{Electronic reference}

Shane Alcobia-Murphy, "Snared by Words": Trauma and the Shoah in the Poetry of Medbh McGuckian », Études irlandaises [Online], 36-1 | 2011, Online since 30 June 2013, connection on 20 April 2019. URL : http://journals.openedition.org/etudesirlandaises/2163; DOI : 10.4000/ etudesirlandaises. 2163

\footnotetext{
This text was automatically generated on 20 April 2019.

(c) Presses universitaires de Rennes
} 


\title{
"Snared by Words": Trauma and the Shoah in the Poetry of Medbh McGuckian
}

\author{
Shane Alcobia-Murphy
}

1 Medbh McGuckian's writing is characteristically appropriative: each poetic text is woven together using phrases and images plucked from myriad sources. A close study of her word-hoard, the papers and manuscripts kept in the Special Collections Department at the Robert W. Woodruff Library, Emory University, demonstrates that her notebooks constitute a diary of her reading. She creates word-lists compiled whilst consulting biographies, critical works, history books and other (often arcane and diverse) genres, and then subsequently constructs poems from these quotations. As she states: "I like to find a word living in a context and then pull it out of its context. It's like they are growing in a garden and I pull them out of the garden and put them into my garden, and yet I hope they take with them some of their original soil, wherever I got them ${ }^{1 "}$. In this article I want to tend to one recently planted corner of this garden where she has created poems from studies related to the Shoah and explore the means by which trauma is inscribed therein.

"To write about the Holocaust, and to write criticism on a text, any text, that acknowledges the Holocaust", argues Robin Silbergleid, "is necessarily to engage in a conversation about literature and ethics". One objection raised against writing about the Shoah is that the very idea of genocide is unthinkable and therefore unrepresentable. As another writer has put it, "[n]o symbolic universe grounded in humanistic beliefs could confront the Holocaust without the risk of being shaken to its foundations" ${ }^{3}$ " Indeed, survivors often face the dilemma of being at once impelled to bear testimony whilst simultaneously finding the ordeal either intolerable or unfeasible. The problem is not due to the limits of memory but, as Laurence Kirmayer argues, it lies in "the inadequacy of ordinary words to express all they have witnessed"; the event presented "an incomprehensible catastrophe that undermines the very possibility of coherent narrative 4". The traumatised survivor carries "an impossible history within them ${ }^{5}$ ", a personal 
history which they strive to communicate and over which they wish to gain mastery; yet it is also one which defies narrativisation. While "stories are a mode of symbolic structure that constructs identity", trauma by nature is "that which evades structure and shatters identity ${ }^{6}$. The mind rebels against the recollection of traumatic memories and actively distorts and fragments the ensuing narrative. Thus, as Gabriele Schwab in her recent study of life-writing, trauma and trans-generational suffering has argued, "[w]riting from within the core of trauma is a constant struggle between the colonizing power of words and the revolt of what is being rejected, silenced. [...] Trauma as a mode of being halts the flow of time, fractures the self, and punctures memory and language ${ }^{7 "}$.

If, for the traumatised survivor, narrativisation of genocide is psychically problematic, for the creative writer who wishes to make art out of such atrocity the dilemma is of an ethical order. Many commentators regard art as an unconscionable obtrusion on the Shoah: while Berel Lang has condemned the fictive dimension of artistic production ("literary representation imposes artifice, a figurative mediation of language, and the contrivance of a persona - that is, a mask - on the part of the writer"), Theodor Adorno famously castigated the distortive "aesthetic principles of stylization" with which art transfigures and strips genocide of its horror, thus doing injustice to its victims ${ }^{9}$. Art, then, is said to render genocide knowable, its formal strategies containing and aestheticising the suffering; narrative may offer closure, yet such atrocity resists being closed off. Equally, art may constitute a second form of subjection for the victim since, as is implied in Adorno's critique, the writer may fall into the double trap of sensationalism and voyeurism. As the Oxford academic Christopher Ricks notes, "atrocity may get flattened down into the casually 'atrocious', or it may get fattened up into that debased form of imagination which is prurience ${ }^{10}$ ". In such a situation, writers must be vigilant against simply treating the Shoah as a fashionable or convenient topic. "The burden which the writer's conscience must bear", writes the poet Geoffrey Hill, "is that the horror might become that hideously outrageous thing, a cliché. This is the nightmare, the really blasphemous thing: that those camps could become a mere 'subject'11". However valid such reservations may be, an artist within his or her text can remain vigilant against voiding atrocity of its true horror. Indeed, as Ezrahi contends, "[i]t may be precisely in its resistance to conceptual abstraction, to psychological reductionism, that art as a version of historical memory can provide form without fixing of meaning, insight without explanation, for the recovered events ${ }^{12}$ ". The subtle ambiguities of art, with its allusive and often elusive strategies, can open up the event for the contemporary reader thereby resisting closure. Yet if the artist is not a survivor and has little connection to the Shoah, does he or she have a right to treat it as an object of scrutiny and as a subject for art?

Is it morally acceptable to speak at all about an atrocity one did not really know? Is it permissible to use our distance from the events of the Shoah as an enabling conduit of their imaginative reconstruction? And how can writers reconstruct those events without giving them an aesthetic order or finish that makes them assimilable and thus frighteningly admissible (or repeatable) ${ }^{13}$ ?

Susan Gubar argues that even the most ethically-minded poets (and scholars) feel a modicum of shame when depicting the suffering of others and that they "mistrust their right to speak, even as they attest to the means by which they speak ${ }^{14 "}$. Medbh McGuckian is one such poet and in "Goddess of the Candlelight during Childbirth" ${ }^{15}$ " she engages with and quotes from Gubar's study, along with two other equally unacknowledged sources ${ }^{16}$, to create a poem which self-reflexively signals the 
impossibility of fully comprehending the Shoah. Instead of narrative precision and closure, the poem is marked by fragmentation and associational logic; rather than presenting a narrative of trauma, it circles around and gestures towards it. As Jenny Edkins argues with regard to the inexpressibility of trauma, "We cannot try to address the trauma directly without risking its gentrification. We cannot remember it as something that took place in time, because this would neutralise it. All we can do is "to encircle again and again the site" of the trauma, "to mark it in its very impossibility ${ }^{17 "}$ " The text mimics the cryptonymic narrative whereby trauma is revealed in the distortions, gaps and fragmentations of language. Within such a text, what Schwab calls "the buried ghosts of the past" emerge "to haunt language from within, always threatening to destroy its communicative and expressive function ${ }^{18}$ ".

\begin{tabular}{|l|l|}
\hline $\begin{array}{l}\text { the weekday gods (RG 230); blocked the } \\
\text { windows with thorns (RG 231); fires of } \\
\text { male }\end{array}$ & $\begin{array}{l}\text { The weekday gods have blocked the windows with } \\
\text { thorns. } \\
\text { We breathe nothing but working class blue, fires of } \\
\text { male }\end{array}$ \\
$\begin{array}{l}\text { olive (RG 114); yellow roses (SG 216) } \\
\text { Olive, the heavy grace of deeper yellow roses. }\end{array}$ \\
$\begin{array}{l}\text { star risings and settings (RG 230); The } \\
\text { tangible }\end{array}$ & Star risings and settings are such dangerous angels. \\
large red & Rounded up to eat grass in the town square. \\
J (SG 31); rounded up to eat grass in the \\
town
\end{tabular}

5 The opening stanzas (cited above right; sources quoted on the left) present a series of juxtaposed images which disorientate the reader. Who are the "weekday gods" and why have they blocked the windows with thorns? To whom does "we" refer? What is the connection between the "male olive" and the "yellow roses?" How can a hand be "a large red J"? How can that letter "eat grass" and in which "town square" does this activity take place? As readers, we bear witness to a speaker for whom language is in pieces due to an unspecified traumatic event, one which cannot be contained within a fully comprehensible narrative because, in Blanchot's terms, "the disaster de-scribes ${ }^{19}$ ". The poet, of course, has undergone no such trauma and the lines imitatively advance a cryptonym narrative. Uncovering the sources and reading them alongside each other enables us to discern the rationale behind such imitation.

6 The first line presents a tension between, on the one hand, faith in a coherent belief system which may ultimately grant the individual protection from harm and, on the 
other, the individual's lack of agency and a sense of being at the mercy of inscrutable forces. While the source text indicates that the placing of thorns in the window at the time of a birth constituted an apotropaic ritual in ancient Rome (RG 231), "blocked" and "thorns" mark the domestic space in McGuckian's text as unsafe. This is a pattern which is continued in the following lines. Although the stanza's birth imagery is connected with catarchic astrology ("star risings and setting") to show how infants are placed under the care of a supervisory divinity (Candelifera, who is "connected with the candle-light during childbirth"), the purificatory and protective images of fire associated with both the birth of the individual and of the nation ${ }^{20}$ are rendered wholly ironic when conjoined with "the heavy grace of deeper yellow roses". "Grace" refers to the bestowing of the free favour of God as manifested in the salvation of sinners, yet what is granted in this instance does not constitute a blessing; rather, the image is taken from a passage in which Gubar cites from Gertrude Stein's "Adler" to describe the hue of the corpses of dead Jews at Treblinka, "those with gold in their mouths, and those with skin / the colour of yellow roses" (SG 216). The "fires", then, have less to do with the purificatory rites on the eve of Parilia (the birth-date of Rome) than with the concentration camps' crematoria. Such is the destination for those who had been subject to a systemic process of othering enshrined within German laws and regulations. The poem quotes from Gubar's text to indicate how the Jews became dehumanised: categorised by and reduced to an alphabetical sign - "passports stamped with a large, red J" (SG 31) - they are further forced to conform to the Nazi's conception of them as animals, "rounded up [...] to eat grass in the town square" (SG 31). Throughout the opening stanzas, then, language has become an unstable system with each image having a double, and self-cancelling, signification: birth-death; protection-imprisonment; purification-destruction.

7 However, what is one to make of "The tangible hand at the centre of things"? As a trope the hand may indicate authorship and, as it is "at the centre", it may signify control; however, the word "things" subverts the idea of mastery as it implies both objectification and imprecision. In fact, the stanza conveys an inexorable process of dehumanisation, from human subject ("hand"), to object ("thing") and finally, to a sign ("J"). Yet the hand also belongs to a female figure which the poem goes on to describe:

\begin{tabular}{|l|l|}
\hline lines of darkness put around the heel of her & $\begin{array}{l}\text { Lines of darkness put around the heel of her } \\
\text { hand }\end{array}$ \\
hand (TC 134); cursive grey (TC 135); barely & On its cursive grey surroundings \\
does its work of holding the cashmere & Shiver into strong silver-it barely does its work \\
shawl (TC 138) & Of holding the cashmere shawl. \\
\hline
\end{tabular}




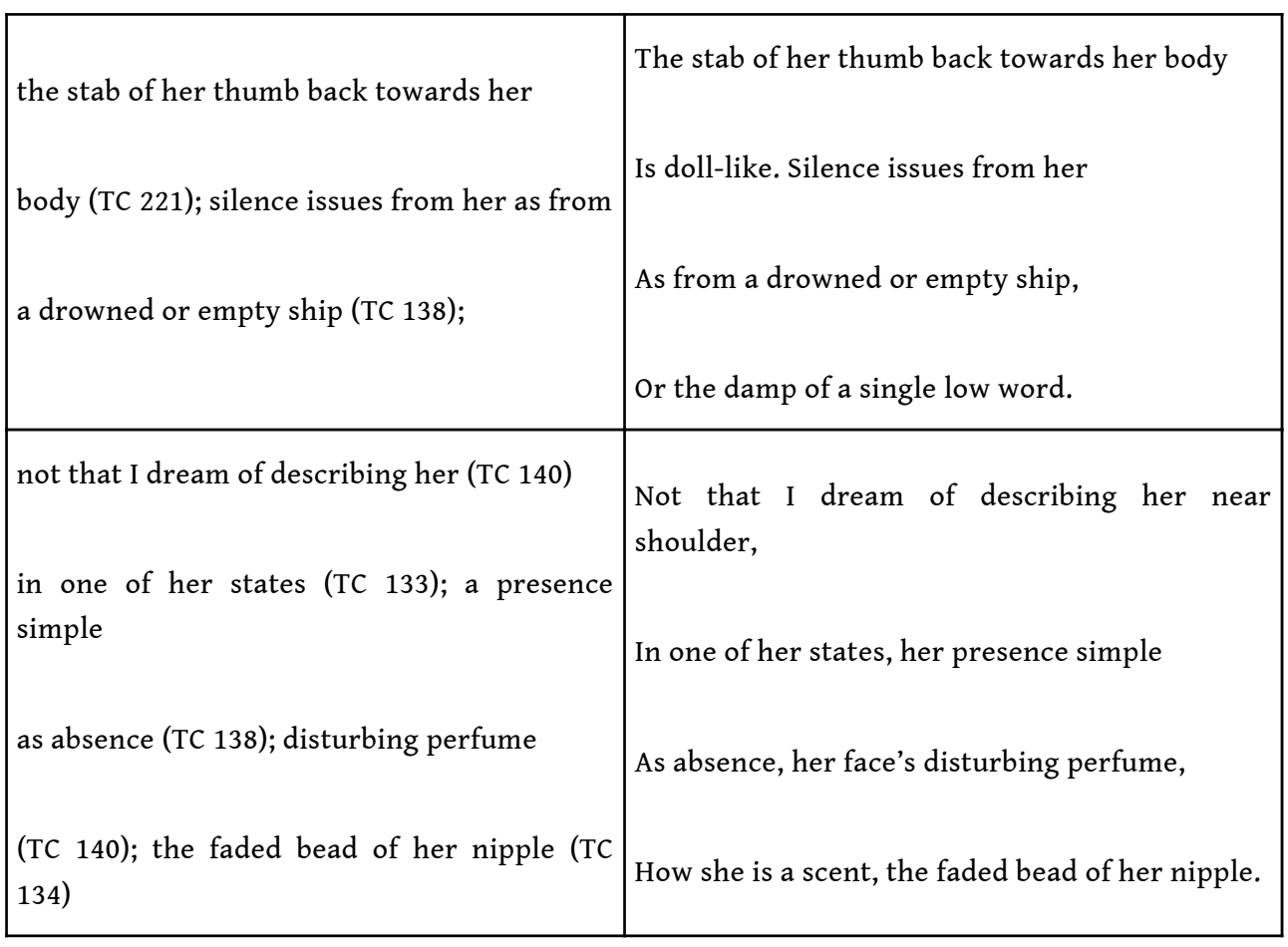

On the surface, these stanzas overtly mark the trauma which they cannot narrate: the apparent solidity of the body dissipates and the text is marked by "silence", "absence", that which is "faded" and empty. Indeed, since the speaker declares that she would "not dream of describing her near shoulder" - instead, she de-scribes the subject's body - one could argue that McGuckian conforms to Gubar's conception of the hyper-sensitive poet who must insistently dwell on her authority to speak for or about the victim: "[her] scrupulous scrutiny of [her] own warrant for composing and [her] wariness about retrospection manifest how creative analyses of the Shoah resist exploitative rhetoric" (SG 30). Yet the poem's deployment of corporeal imagery is more complicated than this : not only does it mark the site of trauma and imitatively depict the ways in which such trauma fragments narrative, it reveals (via the source text from which the images are quoted) the fear which lay behind the Nazi's autocratic control, namely contagion (the blurring of distinctions between the Aryan and the Jew).

9 The text establishes a parallel between a stricken Jewish figure in the first two stanzas and an objectified female figure in the remaining stanzas. The "hand at the centre of things" belongs to the subject of Edouard Manet's Olympia (1863), a painting which, according to T. J. Clark, was shocking when displayed at the Paris Salon in 1865 because the nude body was unfixed and refused categorisation. In nineteenth-century Paris, the prostitute was a social 'other' and was by necessity categorised and objectified "in the files of the police, a number, apart from all social beings" (TC 103). By contrast, the category of courtisane was more acceptable and "was what could be represented of prostitution" (TC 109). Manet, however, renders unclear the distinction between the two; as Clark argues, "Olympia is depicted as nude and courtisane, but also as naked and insoumise; the one identity is the form of the other, but the two are put together in such a way as to make each contingent and unfinished" (TC 131). Each quotation from Clark that McGuckian cites is an example of this deliberate blurring: Olympia's face is described as the "disturbing perfume of a fleur du mal"; "the faded bead of her nipple" (TC 134) makes 
the body indefinite; the placement of the hand disobeys "the rules of the nude" (TC 136) as it fails "to enact the lack of the phallus" (TC 135). What was so unacceptable about Olympia for contemporary reviewers was that her physical body could not be categorised, hence it lacked a determinate place in the social body; thus, the image challenged and subverted not only conventional codes of representation, but signalled the ways in which the strict boundaries upon which an entire class system had been founded were, by the mid-nineteenth century, being eroded. Olympia's erasure of clear distinctions reflects the degree of social mixing and free circulation amongst the different classes and this reflected wider "fears of insurrection" (TC 105).

Thus, while McGuckian's splicing together of quotations in "Goddess of the Candlelight during Childbirth" serves to encircle the site of trauma and indicate how the catastrophic event annuls "the possibility of recounting the totality" by presenting "speech in pieces, splinters and fragments of speech ${ }^{21}$ ", the specific content of her quotations reveals the cause of that trauma. She parallels two instances of social control which, stemming from a fear of contagion, objectify and dehumanise the individual. Yet while her poem graphically depicts the victim and appears to lay the female body open to our scopic gaze, she resists objectifying her. Indeed, just as Manet's Olympia blurs distinctions and resists categorisation, so too does McGuckian's text. Language here becomes an unstable system due to the deployment of ambiguous imagery and the withholding of information about the sources (thereby refusing to provide the reader with a key to read the poem). Her work, then, resists exploitative rhetoric and refuses to categorise the victim as "other".

11 A more controversial strategy adopted by McGuckian in her attempt to commemorate those who survived the Shoah is the unacknowledged co-option or appropriation of existing testimony within a first-person narrative since such a manoeuvre risks claiming the suffering of others as her own. For example, "So Warsaw's Coming to Wait on Us Now ${ }^{22}$ " is, to all appearances, a lyric poem in the sense that it seems to give direct expression to a state of mind or a process of perception and feeling (the opening stanzas are on the right; the source text is on the left) :

\begin{tabular}{|l|l|}
\hline The war kept going on and on (G 426) & The war kept brewing. On and on. \\
$\begin{array}{l}\text { And we were rotting away (G 426); Who would } \\
\begin{array}{l}\text { Have thought it would go on like this so } \\
\text { long? (G 415) }\end{array}\end{array}$ & We were rotting away. Who would \\
\hline $\begin{array}{l}\text { I want to escape to the Old Town (G 411) } \\
\text { I felt as if I were in some strange German city, }\end{array}$ & I wanted to escape to the Old Town. \\
where I should feel afraid of the stones under my feet (G & German city crippled by the stones \\
317) & Under my feet. \\
\hline
\end{tabular}




\begin{tabular}{|l|l|}
\hline I just kept going in circles doing nothing (G 428) & $\begin{array}{l}\text { I kept going in circles doing } \\
\text { nothing. } \\
\text { "I have so much to say to you I prefer to keep }\end{array}$ \\
silent" (G 432); snared by words (G 253) & I had so much to say, I preferred \\
\end{tabular}

For the reader who is unaware of McGuckian's practice of composing poetic centos and who does not realise that the poem is based on Michal Grynberg's Words to Outlive Us ${ }^{23}-\mathrm{a}$ collection of prose narratives centred around twenty-nine eyewitness testimonies from Jews who were either confined to the Warsaw Ghetto or hiding in other parts of the city there is a risk of viewing the poem as, in M.H. Abrams's definition of the lyric poem, a "fragment of reshaped autobiography ${ }^{24 "}$. Therefore, there are two issues at stake here: firstly, the appropriation of eyewitness testimony - six of the quotations come from Dawid Fogelman's narrative, with a single quotation taken from testimonies by Stefan Ernest and Franciszka Grünberg - for aesthetic purposes; secondly, the apparent ventriloquising by the poet of another's suffering through the lyrical " $\mathrm{I}$ ". However, recent critical and theoretical arguments have persuasively reminded the reader not to confuse the poet with the speaker when analysing a lyric poem ${ }^{25}$, and, in any case, it is perhaps best to regard this text as a dramatic monologue, one which plays out a psycho-drama not experienced by the poet herself. Still, how is one to answer the charge of impropriety regarding the use of the words of others? The answer lies in discerning the poem's thematic focus and purpose.

The text presents a retrospective narrative which holds in tension times past and present. The speaker reveals that her identity had unravelled due to enforced segregation within the Ghetto; what the speaker describes in the second stanza is a form of self-alienation (figured in the text as a misrecognition of place). The impulse to escape leads only to inaction and a circling back upon herself (spatially and mentally). For her, words were to be mistrusted and what resulted was silence: she "preferred not to be snared by words". This scenario is presented in contrast with her present state since she now relates her history. In the opening tercet the speaker's mind circles back to the past in order to describe a traumatic condition; however, the use of the past continuous tense for verbs which signify a cycle of generation and degeneration ("brewing" ; "rotting") hints that the trauma has not been kept at bay. Indeed, "on and on" signals continuing distress: the phrase not only repeats the semantic content of the opening sentence, thus disrupting the flow of the narrative and allowing it to circle back on itself, the narrative becomes fragmented since the sentence lacks grammatical structure. Language in the poem ceases to function properly. The question asked in the sentence that follows - "Who would have thought it would so long? " - fails to provide resolution and it cannot be answered since it lacks the implied verb ("last"). Thus, the speaker is seen to void her own discourse (consciously or unconsciously) of any sense of ending. What we have here is trauma in the sense of "a disease of time [which] permits the past to relive itself in the present, in the form of intrusive images and thoughts ${ }^{26 "}$. Because trauma is a "breach in the mind's experience of time ${ }^{27}$ " the standard experience of time as a linear, chronological progression from past to present to future is disrupted. Traumatic events are timeless: for the victim, trauma appears to have "no beginning, no ending, no before, no during, and 
no after ${ }^{28}$. Therefore, McGuckian's selection and juxtaposition of quotations does not seek to appropriate the eye witnesses' suffering; rather, she fragments the oral testimony to convey a sense of ongoing suffering often missing from Words to Outlive Us. While the oral testimonies collected in Grynberg's work are undoubtedly authoritative, moving and of real historical value, the majority of the narratives present a retrospective coherence. Trauma, however, affects the ability to place memories of events into a coherent and linear narrative: when trauma occurs "time cannot be made to tell a [...] story, cannot be restored to narrative coherence, because violence shatters time ${ }^{29}$ ". Thus, McGuckian's poem dislocates the narratives to recreate the traumatic condition.

She deploys many of the same strategies in "Skirt of a Thousand Triangles 30 ", a poem based on Michelangelo in Ravensbrück, Karol Lanckoronska's account of her wartime experiences, particularly her time in Ravensbrück concentration camp ${ }^{31}$. We again have a retrospective narrative, one which appropriates first-hand testimony by a camp survivor. The opening two-line stanza presents a tension between the defensive urge to deny one's experience and the contrary impulse to bear witness (the text is on the right, the source is on the left):

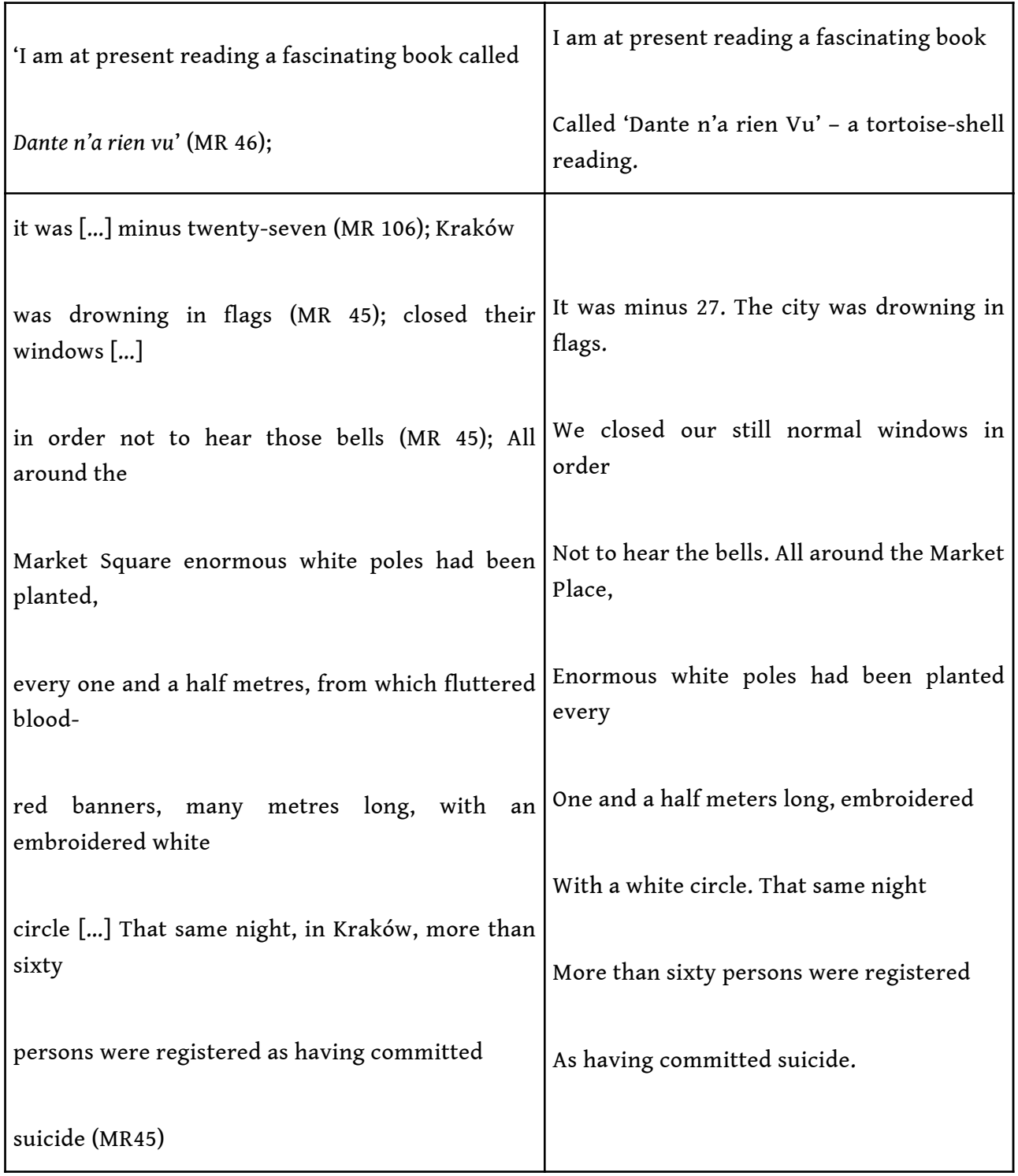




\begin{tabular}{|c|c|}
\hline I had quickly sat down with my back to the & Having quickly sat down with my back \\
\hline $\begin{array}{l}\text { window (MR 79); I could only count the shots (MR } \\
\text { 132) }\end{array}$ & $\begin{array}{l}\text { To the window, I could only count the } \\
\text { shots. }\end{array}$ \\
\hline $\begin{array}{l}\text { the unravelled sweaters and scarves (MR 135); } \\
\text { while I }\end{array}$ & $\begin{array}{l}\text { Not the unravelled scarves. While I was } \\
\text { binding }\end{array}$ \\
\hline $\begin{array}{l}\text { was winding bandages ( } \mathrm{MR} 42) \text {; common-or } \\
\text { garden }\end{array}$ & $\begin{array}{l}\text { Bandages, with my common-or-garden } \\
\text { nerves, }\end{array}$ \\
\hline $\begin{array}{l}\text { nerves (MR 120); told me precisely how to knock } \\
\text { on the }\end{array}$ & $\begin{array}{l}\text { She told me how precisely to knock upon } \\
\text { the door }\end{array}$ \\
\hline $\begin{array}{l}\text { door (MR 42); a house [...] was 'liberated' (MR 64); } \\
\text { The }\end{array}$ & When a house was 'liberated'. \\
\hline $\begin{array}{l}\text { first two days we spent sitting on our suitcases } \\
\text { (MR 40) }\end{array}$ & The first two days we spent \\
\hline
\end{tabular}

Foregrounding the time of writing, the speaker declares that she is reading a book entitled Dante n'a rien $v u$, a title which seemingly corresponds to the reading process which is characterised the by self-protective "tortoise-shell" : Dante saw nothing. Yet that text, properly entitled Dante n'avait rien $v u$, is a testimony by Albert Londres published in 1924, one which offers a critique of French military prisons in the colonies and which bears witness to the atrocities committed by the authorities. The distance between Londres's disposition and that of the speaker mirrors that between the poetic text and its source. Lanckoronska's narrative is intended as testimony. In the prologue she states: "My memoir is meant to be a report - and only a report - of what I witnessed during the Second World War" (MR xxv). In contrast, the poetic speaker's actions in the past are characterised by a wilful blindness to what is happening: the closing of the windows is enacted to affirm normality, yet it is clear that the opposite is the case (the ringing of the bells celebrate the capitulation of France and in the market square the blood-red banners herald the appearance of Nazi swastikas). The strangely passive construction - "More than sixty persons were registered / As having committed suicide" - indicates a failure to comprehend the horror of what is occurring: the human beings have become textualised. The speaker has turned her back on the outside world and can only "count the shots" : there is a deliberate effort not to witness the execution of her fellow citizens. The action of sitting on her suitcase indicates the desire to flee, yet her inaction conveys her lack of agency. In effect, she herself is caught within "the white circle" of the embroidered flag. By reversing the intention and effect of the source text, McGuckian focuses our attention on the understandable, though utterly self-defeating refusal to bear witness to atrocity.

The image of the embroidered flag is picked up on and transformed later in the poem when the speaker, having undergone imprisonment and on point of release, declares, 
"You have to back out / of the cell as you leave, and tread on a rag/On the splintering floor". The source text states that this is a ritual undertaken by anyone leaving the prison cell : "As I was on my way to the door, one of the Ukrainian girls flung herself on me and turned me round to face the cell: 'You have to back out of the cell as you leave. That way you draw us all out after you, and you've got to tread on a rag as you go"' (MR 143). Within the poetic text, the ritual's meaning is clear: it forces the released prisoner to look at and bear witness to her former companions, and to remember them. Incorporated within the poem, it marks a moment when the speaker is no longer self-absorbed, as she was when within the white circle. The fact that the rag is dragged along "the splintering floor" is a significant departure from the source text. The unravelling of this fabric perhaps indicates that a further meaning is to be gleaned from the image as it is one which has its counterparts in the other poems. In "Goddess of the Candlelight during Childbirth" when we are told that Olympia's hand "barely does its work / of holding the cashmere shawl", it is a disruptive moment (a refusal to conceal that which must be hidden). By contrast, in "So Warsaw's Coming to Wait on Us Now", when the speaker's companion "seals herself with her shawl", the speaker herself has a blouse cut for her and she sews it up quickly, an action which is self-protective and serves to resist the hardship she is undergoing. When McGuckian borrows tropes of woven or sewn garments from her sources she not only highlights their status as texts woven together from earlier texts ( textus: tissue of a literary work, literally that which is woven), she is also adverting to a key function behind her reprising of exemplary texts.

In their introduction to Rewriting/Reprising in Literature the editors state that trauma is "a sudden intrusion of the shapeless and the nameless which tears the fabric open, whether it be in the narrative of our lives or in the stories which try to give shape to such disruptive events ${ }^{32}$ ". When attempting to counteract a trauma which not only evades narrative structure but also actively de-scribes it, when "snared by words" in the face of the indescribable, or indeed when faced with describing that for which one has no authority to speak, a writer may delve into the pre-existing word-hoard and, to paraphrase Eliot, use the fragments to shore against the ruins ${ }^{33}$. To do so is to highlight an alternative meaning of reprise, namely the darning of a fabric/text: "rewriting/ reprising may be understood as an endless attempt to heal [...] breaches loaded with silent affects ${ }^{34}$ ". Yet in McGuckian's work her emphasis is not on healing or on the construction of coherent narratives. The tearing, unravelling or divestment of a garment in her work signals her intention to remain truthful to the nature of trauma. Paradoxically, then, her stitching together of fragments from source texts is not intended to grant wholeness, unity or coherence to the original; rather, she uses them to disorientate the reader and make us bear witness to experiences which we cannot fathom.

\section{NOTES}

1. Medbh McGuckian, interview by Helen Blakeman, Irish Studies Review, 11:1, 2003, p. 67. 
2. Robin Silbergleid, “'Treblinka, a Rather Musical Word' : Carole Maso's Post-holocaust Narrative", MFS : Modern Fiction Studies, 53:1, Spring 2007, p. 2.

3. Sidra DeKoven Ezrahi, By Words Alone: The Holocaust in Literature, Chicago, The University of Chicago Press, 1980, p. 1.

4. Laurence J. Kirmayer, "Landscapes of Memory: Trauma, Narrative, and Dissociation", Tense Past: Cultural Essays in Trauma and Memory, eds. Paul Antze and Michael Lambek, New York, Routledge, 1996, p. 174-5.

5. Cathy Caruth (ed.), Introduction, Trauma: Explorations in Memory, Baltimore, The Johns Hopkins University Press, 1995, p. 5.

6. Amos Goldberg, "Trauma, Narrative and Two Forms of Death", Literature and Medicine, 25.1, Spring, 2006, p. 122.

7. Gabriele Schwab, Haunting Legacies: Violent Histories and Transgenerational Trauma, New York, Columbia University Press, 2010, p. 41.

8. Berel Lang, Act and Idea in the Nazi Genocide, Chicago, The University of Chicago Press, 1990, p. xi.

9. Theodor Adorno cited in Irving Howe, "Writing and the Holocaust", Writing and the Holocaust, ed. Berel Lang, New York, Holmes and Meier, 1988, p. 179.

10. Christopher Ricks, The Force of Poetry, Oxford, Clarendon Press, 1984, p. 285.

11. Hill, "Under Judgment", interview with Blake Morrison, New Statesman, 8 February 1980, p. 213.

12. S. D. Ezrahi, op. cit., p. 4.

13. Susan Gubar, Poetry After Auschwitz: Remembering What One Never Knew, Bloomington, Indiana University Press, 2003, p. 29.

14. Gubar, op. cit., p. 29.

15. Medbh McGuckian, "Goddess of the Candlelight during Childbirth", unpublished poem sent to the author, 14 January 2009.

16. Susan Gubar, Poetry after Auschwitz (cited in text as SG); Jorg Rupke, Religion of the Romans, trans. Richard Gordon, Cambridge, Polity, 2007, cited in text as JP; T. J. Clark, The Painting of Modern Life, Princeton, Princeton University Press, 1999, cited in text as TC.

17. Jenny Edkins, Trauma and the Memory of Politics, Cambridge, CUP, 2003, p. 15.

18. Schwab, op. cit., p. 49.

19. Maurice Blanchot, The Writing of the Disaster, trans. A. Smock, Nebraska, University of Nebraska Press, 1986, p. 7.

20. Jorg Rupke's Religion of the Romans outlines how, on the birth-date of Rome, "[o]ne or more fires of male olive-, pine-, juniper- and laurel-branches were lit, and offerings made to Pales, requesting protection from dangers" (p. 114).

21. Marc Nichanian, "Catastrophic Mourning", Loss: The Politics of Mourning, eds. David L. Eng and David Kazanjian, Berkeley, University of California Press, 2003, p. 112.

22. Medbh McGuckian, "So Warsaw's Coming to Wait on Us Now", An Sionnach, 3.1, Spring, 2007, p. 80-2.

23. Michal Grynberg (ed.), Words to Outlive Us: Eyewitness Accounts from the Warsaw Ghetto, trans. Philip Boehm, London, Granta, 2003. Cited in text as G. 
24. M.H. Abrams, Natural Supernaturalism: Tradition and Revolution in Romantic Literature, New York, Norton, 1973, p. 123.

25. See Scott Brewster, Lyric, London, Routledge, 2009, p. 2.

26. Allan Young, The Harmony of Illusions, Princeton, Princeton University Press, p. 7.

27. Cathy Caruth, Unclaimed Experience: Trauma, Narrative, and History, London, The Johns Hopkins University Press, 1996, p. 4.

28. Dori Laub, "Bearing Witness, or, the Vicissitudes of Listening", Testimony: Crises of Witnessing in Literature, eds. Shoshana Felman and Dori Laub, New York, Routledge, 1992, p. 69.

29. Leigh Gilmore, The Limits of Autobiography: Trauma and Testimony, London, Cornell University Press, 2001, p. 92.

30. Medbh McGuckian, "Skirt of a Thousand Triangles", An Sionnach, 3.1, Spring, 2007, p. 79-80.

31. Countess Karolina Lanckoronska, Michelangelo in Ravensbrück : One Woman's War against the Nazis, trans. Noel Clark, London, Pimlico Press, 2007. Cited in text as MR.

32. Claude Maisonnat, Josiane Pacaud-Huguet and Annie Ramel, "Introduction", Rewriting/Reprising in Literature: The Paradoxes of Intertextuality, Newcastle-upon-Tyne, Cambridge Scholars Publishing, 2010, p. XII.

33. T.S. Eliot, "The Waste Land", The Waste Land and Other Poems, repr. 1990, London, Faber, 1921, p. 41.

34. Claude Maisonnat, Josiane Pacaud-Huguet and Annie Ramel, p. XIII.

\section{ABSTRACTS}

Medbh McGuckian's writing is characteristically appropriative: each poetic text is woven together using phrases and images plucked from myriad sources. This article examines how she uses unacknowledged quotations to mark and encircle narratives of trauma. Looking specifically at three poems which take the Shoah as their thematic focus, I explore how she avoids exploitative rhetoric and how she is aware of her lack of authority to speak about or on behalf of the victims.

L'écriture de Medbh McGuckian s'approprie les choses : chacun des textes poétiques est élaboré en reliant, comme en un tissage, des expressions et des images issues de sources multiples. Cet article se penche sur la manière dont elle utilise des citations (dont les auteurs ne sont pas référencés) pour marquer et cerner un discours sur le traumatisme. On prendra pour exemple trois poèmes qui ont pour thème la Shoah, et l'on montrera comment McGuckian se détourne d'une rhétorique qui exploiterait le sujet pour au contraire souligner la difficulté intrinsèque à laquelle elle est confrontée pour parler des victimes, ou en leur nom. 
INDEX

Keywords: McGuckian Medbh, poetry, trauma

Mots-clés: McGuckian Medbh, poésie, trauma

\section{AUTHOR}

SHANE ALCOBIA-MURPHY

University of Aberdeen 